Original Research

\title{
Contributing Factors of Cyberbullying Behavior among Youths During Covid-19
}

\author{
Ira Kusumawaty ${ }^{1}$, Yunike Yunike ${ }^{1}$, Yeni Elviani ${ }^{1}$ and Hidayat Arifin ${ }^{2}$ \\ ${ }^{1}$ Politeknik Kesehatan Kemenkes Palembang, Indonesia \\ 2 Faculty of Nursing, Universitas Padjadjaran, Indonesia
}

\begin{abstract}
Introduction: The use of information technology during the Covid-19 period is inevitable and can lead to cyberbullying. Mental and life health conditions can be threatened due to being the victim of cyberbullying. This study aims to determine the factors that contribute to the formation of cyberbullying behavior among youths in South Sumatra, Indonesia.
\end{abstract}

Methods: A cross-sectional study was undertaken. The population was youths in South Sumatra, Indonesia with a total sample of 213 respondents who were determined based on purposive sampling. The data collection was done by distributing questionnaires via Google Forms. The questionnaire was developed based on the concept of cyberbullying behavior inclusive of repetition, power imbalance, deliberation and aggression. The data was analyzed using ANOVA and MANOVA.

Results: In the study, we found that gender contributes the most to shaping cyberbullying behavior $(p=0.000)$, followed by the parent's occupation $(\mathrm{p}=0.018)$.

Conclusion: It is necessary to establish an interconnected system between parents, youth groups and the education sector to avoid cyberbullying behavior. The ability of youths to adapt constructively to the increasing advancement of information technology and to use it wisely is something urgent that needs to be observed so then the cyberbullying cycle can be eradicated.

\section{ARTICLE HISTORY}

Received: January 18, 2021

Accepted: March 28, 2021

\section{KEYWORDS}

Covid-19; cyberbullying; behavior, youth

\section{CONTACT}

Ira Kusumawaty

$\bowtie$ irakusumawaty@poltekkes

palembang.ac.id

$\ggg$ Politeknik Kesehatan

Kemenkes Palembang, Indonesia

Cite this as: Kusumawaty, I., Yunike, Y., Elviani, Y., \& Arifin, H. (2021). Contributing Factors of Cyberbullying Behavior among Youths During Covid-19. Jurnal Ners, 16(1). 54-59. doi:http://dx.doi.org/10.20473/in.v16i1.24751

\section{INTRODUCTION}

Covid-19 has had a wide impact on various groups regardless of age, socioeconomic level, education level and gender. The use of online communication tools is an inevitable condition and the youth group is the largest group utilizing the internet or online media in their daily life (Oliveira et al., 2018). The number of internet users in Indonesia has exceeded 200 million, which is more than $75 \%$ of the population (Eloksari, 2020). The continuous use of online media with a negative internal motivation can encourage someone to engage in cyberbullying (Cong et al., 2018; Sittichai \& Smith, 2015; Swearer \& Hymel, 2015). Youths are the largest group of information technology users, so they have the biggest likelihood of being involved in cyberbullying (Grunin et al., 2020; Messias et al., 2014). As a form of psychological disorder, cyberbullying began to occur after the development of traditional bullying into bullying that occurs due to technological improvements (Notar et al., 2013; Ronis \& Slaunwhite, 2019). Freedom is a feeling that youths experience when in cyberspace due to the ease of making friends or interacting with many parties. This characteristic is why teenagers are often trapped in the cycle of cyberbullying. Oppression, harassment, humiliation and violence are the consequences that often arise due to the uncontrolled use of communication technology (Chan et al., 2021; López-Castro \& Priegue, 2019). It is known that on average, among the $25 \%$ of victims of bullying, 10\% have experienced being bullied online, in addition to by telephone at nearly $10 \%$ and via text message almost exceeding the percentage of $8 \%$ (Notar et al., 2013).

Cyberbullying involves bullying through the use of electronic venues such as instant messaging, e-mail, chat rooms, websites, online games, social 
networking sites, and text messaging (Wade \& Beran, 2011). Furthermore, cyberbullying is an emerging public health concern among youths with established links to physical and mental health problems. Intimidation has been carried out by the cyberbullying perpetrators by utilizing technology in the form of text messages, e-mails, chat rooms, social networking sites, web or online games. Cyberbullying is becoming a global social and school problem. Multiple studies worldwide have reported cyberbullying prevalences among students (Notar et al., 2013; Wade \& Beran, 2011). Cyberbullying has continued to escalate unexpectedly to the point of becoming a worldwide problem.

Many studies have tried to explain the causes of cyberbullying. The results of the research by (Baldry et al., 2015; Hellfeldt et al., 2020) show that individual social conditions are associated with cyberbullying and that there is only a slight difference between the victims of bullying in terms of gender. Facebook users report higher rates of extroverts and lower levels of awareness than non-users (Burešová et al., 2015; Sindermann et al., 2020). One indicator of the possibility of being a cyberbullying actor is a lack of empathy for the victims of cyberbullying. (Balakrishnan \& Fernandez, 2018; Doane et al., 2014) Bullying is more common among boys than girls (Sharma et al., 2017).

Cyberbullying is generally related to differences in power between the perpetrator and the victim. The victim is the party that has less power, meaning that they are unable to fight the perpetrator (Auemaneekul et al., 2020; Chan et al., 2021). This condition results in the development of serious problems, not only regarding their physical health conditions but also their mental health (Messias et al., 2014; Selkie et al., 2016). Based on (Grunin et al., 2020), due to the use of social media, the victim's social emotional condition is disturbed. The sad condition occurs where only $5.1 \%$ have reported cyberbullying, 5\% have reported being the victims of bullying and only $9.5 \%$ have reported being either the perpetrator or victim of cyberbullying (Hemphill \& Heerde, 2014). If cyberbullying is not immediately addressed, it can cause mental health problems. Suicide cases have been reported as a result of cyberbullying (Grunin et al., 2020; Notar et al., 2013) and more than $10 \%$ of cases of suicide are due to cyberbullying(Messias et al., 2014). Almost 50\% of victims did not report the abuse they experienced and only $10 \%$ of victims told their parents about the bullying (Li, 2010).

The physical, psychological, and academic documentation correlates the two types of bullying as they resemble one another (Domínguez-Hernández et al., 2018; Notar et al., 2013). Consistent with the research on traditional bullying, the possible negative effects of cyberbullying were the most pronounced for the cyber-bully/victim participants, especially males. These individuals generally reported experiencing more negative physical, psychological and academic effects due to electronic bullying than those in other groups (Messias et al., 2014; Notar et al., 2013). In order to find the best solution, this study aims to determine the factors that contribute to the formation of cyberbullying behavior among youths in South Sumatra, Indonesia.

\section{MATERIALS AND METHODS}

The study used a cross-sectional design, and the research process was ongoing for 6 months from March to August 2020. The population in this study consisted of youths who used online media the most living in the South Sumatra province. The total sample was 213 respondents obtained using the purposive sampling technique. The inclusion criteria were youths aged 15 to 25 years old who use gadgets every day with a willingness to be respondents in the study. Respondents who could not complete join the study and those who did not complete the questionnaire were excluded.

The questionnaire included of age, education level, youth status, residence, gender and the parent's occupation as the independent variables and cyberbullying behavior as the dependent variable. Cyberbullying behavior was categorized into four groups, namely low, moderate, high and very high cyberbullying behavior. The questionnaire used was a modification of the cyberbullying behavior scale developed by (Langos, 2012) which includes repetition, a power imbalance, and deliberate and aggression components. Each component was assessed using 8 statements with a Likert scale (strongly to strongly disagree). The questionnaire consisted of 32 questions (17 favorable and 15 unfavorable statements). Validity and reliability tests were carried out with a Cronbach's alpha score of 0.931.

The data collection process carried out was through the distribution of the Google Form survey through a WhatsApp group. This, in turn, was disseminated to other WhatsApp groups. On the first sheet of the Google Form, the researcher includes the title, research objectives, respondent criteria, informed consent form and rewards. Rewards were given in the form of pulses for the respondents who were willing to be involved in the research. The data was then collected, screened, and compiled for further analysis.

The analysis in the study was assisted by the IBM SPSS 25 software. Furthermore, the data was analyzed using the ANOVA and MANOVA tests with a significance level of 0.05 .

Ethical clearance was issued by the Ethics Committee of Politeknik Kesehatan Palembang number: 277/KEPK/Adm2/VI/2020. To ensure the confidentiality of the information submitted, the respondents only needed to write their initials. In addition, the research was not compulsory to engage in, so the respondents were able to resign at any time.of the Faculty of Medicine, Airlangga University on April 27, 2020. 


\section{RESULTS}

Table 1 shows the diversity of the characteristics of the research respondents. The majority of the respondents were aged 15-18 years old and female with a mostly high school level of education. Most were the oldest child. The respondents predominantly lived with their parents. The majority of the respondent's parents had a permanent occupation. From the results of this study, we found that most respondents experienced low cyberbullying behavior, followed by high cyberbullying behavior.

The ANOVA statistical test shows there is a significant relationship between residence, gender and the parent's occupation with cyberbullying behavior. On the other hand, there is no significant relationship between age, education level and the youth's status with cyberbullying behavior (Table 2). The MANOVA analysis shows that the variables of gender and the parent's occupation are more likely to be linked to cyberbullying behavior (Table 3).

Table 1. Characteristic Respondents ( $\mathrm{n}=213)$

\begin{tabular}{|c|c|c|}
\hline Category & $\mathbf{n}$ & $\%$ \\
\hline \multicolumn{3}{|l|}{ Age } \\
\hline $15-18$ years old & 134 & 62.91 \\
\hline $19-25$ years old & 79 & 37.09 \\
\hline \multicolumn{3}{|l|}{ Gender } \\
\hline Male & 70 & 32.86 \\
\hline Female & 143 & 67.14 \\
\hline \multicolumn{3}{|l|}{ Education Level } \\
\hline Secondary education & 3 & 1.41 \\
\hline High education & 210 & 98.59 \\
\hline \multicolumn{3}{|l|}{ Youth status } \\
\hline The oldest child & 85 & 39.91 \\
\hline The middle child & 64 & 30.05 \\
\hline The youngest child & 64 & 30.05 \\
\hline \multicolumn{3}{|l|}{ Residence } \\
\hline Rent & 43 & 20.19 \\
\hline Live with parents & 158 & 74.18 \\
\hline Live with relatives & 12 & 5.63 \\
\hline \multicolumn{3}{|l|}{ Parent's occupation } \\
\hline Permanent & 164 & 77 \\
\hline Temporary & 49 & 23 \\
\hline \multicolumn{3}{|l|}{ Cyberbullying behavior } \\
\hline Low & 77 & 36.15 \\
\hline Moderate & 54 & 25.35 \\
\hline High & 69 & 32.39 \\
\hline Very high & 13 & 6.10 \\
\hline
\end{tabular}

Table 2. The relationship between the independent variable and the dependent variable

\begin{tabular}{llcccc}
\hline \multicolumn{1}{c}{ Independent Variables } & Model & $\begin{array}{c}\text { Sum of } \\
\text { Square }\end{array}$ & $\begin{array}{c}\text { Mean } \\
\text { Square }\end{array}$ & F & p \\
\hline Age & Regression & 0.440 & 0.440 & 0.474 & 0.492 \\
Education level & Residual & 196.039 & 0.929 & & \\
& Regression & 0.022 & 0.022 & 0.023 & 0.879 \\
Youth status & Residual & 196.457 & 0.931 & & \\
& Regression & 1.377 & 1.377 & \multirow{2}{*}{1.489} & 0.224 \\
Residence & Residual & 195.102 & 0.925 & & \\
Gender & Regression & 3.674 & 3.674 & 4.021 & 0.046 \\
& Residual & 192.805 & 0.914 & & \multirow{2}{*}{0.000} \\
Parent's occupation & Regression & 35.917 & 35.917 & 47.200 & \\
& Residual & 160.562 & 0.761 & \multirow{2}{*}{5.033} & 0.026 \\
\hline
\end{tabular}

Table 3. Variables that are most closely related to bullying behavior

\begin{tabular}{lcccc}
\hline \multicolumn{1}{c}{ Dependent Variable } & $\begin{array}{c}\text { Type III Sum } \\
\text { of Squares }\end{array}$ & df & Mean Square & F \\
\hline Parent's occupation & 1.763 & 3 & 0.588 & 3.416 \\
Gender & 9.883 & 3 & 3.294 & 18.553 \\
Residence & 1.649 & 3 & 0.550 & 2.353 \\
Age & 0.335 & 3 & 0.112 & 0.473 \\
Education Level & 0.004 & 3 & 0.001 & 0.000 \\
Youth status & 3.521 & 3 & 1.174 & 0.702 \\
\hline
\end{tabular}




\section{DISCUSSION}

In this study, we found that gender and the parent's occupation result in a greater likelihood of experiencing cyberbullying behavior. There are seven characteristics of cyberbullying consisting of conveying negative information indirectly through electronic applications intended to hurt the victim. It can occur repeatedly with an ongoing impact. The perpetrator can be either an individual or part of a group. The identity of the perpetrator is often hidden and it occurs all of the time (Cong et al., 2018). The use of information technology cannot be separated from the teenagers' lives, especially during the Covid19 period which requires that everything be done online. This condition provides opportunities for cyberbullying behavior as a behavior that is often engaged in by youths based on certain motivations (Cong et al., 2018; Swearer \& Hymel, 2015). the desire to take revenge, to divert their feelings and to make their feelings more comfortable are some of the internal motivations for cyberbullying (Chan et al., 2021; Slaninova et al., 2011). In other words, feelings of frustration and aggression encourage youths to engage in virtual bullying.

In this study, gender was found to be a factor related to cyberbullying behavior. There is a tendency for there to be a difference in the behavior patterns when the youths are female when utilizing technological advances compared to male youths. Several studies have explained that male youths have a higher tendency to bully (Grunin et al., 2020; Wiguna et al., 2018). In this study, the variable of living with their family was one of the drivers of cyberbullying behavior. However, this condition involves a very long process. The previous research (Chan et al., 2021; Paisi-Lazarescu, 2014) explains the relationship between life with their family and the possibility of cyberbullying behavior. This is possible because during the Covid-19 period, there were health protocols that must be adhered to avoid crowds, including staying at home more often. Girls are at a higher risk of committing suicide than boys as a result of being the victim of cyberbullying (Shireen et al., 2014).

The socioeconomic condition of the family in this study was found to be related to cyberbullying behavior. The family socio-economic condition is determined by the family work status and specifically, the parent's occupation. The results of this research reveal that socio-economic conditions have an effect on the increasing number of cyberbullying cases (Grunin et al., 2020; López-Meneses et al., 2020). This can occur because the socioeconomic condition of the family, which can be determined by the amount of family income, affects how the family meets the needs of its family members, including the youths. The ease with which youths obtain the desired facilities encourages character building, particularly among those who always experience ease when getting what they desire. This indirectly contributes to the character building of youths through friendship.
Being accustomed to always getting something that they crave in the family encourages youths to get the same treatment in their friendships. When a friend is unable to fulfill this wish, there will be a compulsion of will so then the wish can be fulfilled by the friend. As the characteristics of youths include the freedom to express their will and feelings, they do not have the maturity to anticipate their impact on the resulting behavior (Burešová et al., 2015).

Various studies discussing the effects of cyberbullying in the literature have identified in the form of suicidal ideas and attempts as a symptom of various psychiatric disorders. There is also the emergence of depression and excessive anxiety, including an addiction to illegal substances. These varied conditions lead the perpetrator to intimidate the victim. This condition is very much influenced by the sex (Grunin et al., 2020) and age group of the perpetrator and victim respectively (Burešová et al., 2015). However, in this study, age was not associated with cyberbullying behavior because the majority of respondents were in the same age range.

The incidence of cyberbullying is very much influenced by the environment where the perpetrator is, such as school. It is known that there is a positive effect following the school's involvement in overcoming the suicide attempts of victims due to cyberbullying. It is necessary to establish a psychological support program for the victims of bullying and to enforce strict rules against the perpetrators of bullying. The victims of bullying are weak individuals who are physically and psychologically incapable, socially isolated, always alone, insecure and have low self-confidence. All children can become victims of bullying, and the youths who are victims of bullying commonly have the characteristic of being easily anxious with low self-esteem (Balakrishnan \& Fernandez, 2018; Palermiti et al., 2017). Some of the traits of youths who have the potential to become the victims of bullying include isolation and having no friends, easily experiencing anxiety, feeling insecure and being less able to make friends, not having the courage to defend themselves, crying easily, giving up easily, possibly experiencing violence at home and having learning difficulties.

Several limitations have been found in this study. Collecting the data during the Covid-19 pandemic required the researchers to use a Google Form as the researchers could not meet face to face with the respondents. The researchers also did not conduct indepth interviews related to cyberbullying behavior, which is useful when seeking to further explore the problem of cyberbullying.

\section{CONCLUSION}

Youths are a group that is vulnerable to becoming either the perpetrators or victims of cyberbullying. Covid-19 has created a situation where the fulfillment of their daily needs is mostly obtained through cyberspace. Different approaches are needed 
regarding males and females when regulating and monitoring the use of information technology so as not to increase the number of victims of bullying through technological advances. It is necessary to create a harmonious atmosphere of togetherness at home, so then the youths can find comfort among their family members. This will allow the emotional atmosphere formed by the youth's psychology to be formed optimally. A massive project is needed that involves their parents, the education sector and the youth's closest environment to develop their mental health condition optimally. The establishment of a cyberbullying prevention project is expected to improve the coping mechanisms of youths today.

\section{REFERENCES}

Auemaneekul, N., Powwattana, A., Kiatsiri, E., \& Thananowan, N. (2020). Investigating the mechanisms of theory of planned behavior on Cyberbullying among Thai adolescents. Journal of Health Research, 34(1), 42-55. https://doi.org/10.1108/JHR-02-2019-0033

Balakrishnan, V., \& Fernandez, T. (2018). Self-esteem, empathy and their impacts on cyberbullying among young adults. Telematics and Informatics, 35(7), 2028-2037. https://doi.org/10.1016/j.tele.2018.07.006

Baldry, A. C., Farrington, D. P., \& Sorrentino, A. (2015). "Am I at risk of cyberbullying"? A narrative review and conceptual framework for research on risk of cyberbullying and cybervictimization: The risk and needs assessment approach. Aggression and Violent Behavior, 23, 36-51. https://doi.org/10.1016/j.avb.2015.05.014

Burešová, I., Vrbová, M., \& Čerňák, M. (2015). Personality Characteristic of Adolescent Selfharmers. Procedia - Social and Behavioral Sciences, 171, 1118-1127. https://doi.org/10.1016/j.sbspro.2015.01.274

Chan, T. K. H., Cheung, C. M. K., \& Lee, Z. W. Y. (2021). Cyberbullying on social networking sites: A literature review and future research directions. Information and Management, 58(2), 103411. https://doi.org/10.1016/j.im.2020.103411

Cong, T. Van, Ngoc, N. P. H., Weiss, B., Luot, N. Van, \& Dat, N. B. (2018). Definition and Characteristics of "Cyberbullying" among Vietnamese Students. VNU Journal of Science: Education Research, 34(4). https://doi.org/10.25073/2588-

1159/vnuer.4212

Doane, A. N., Pearson, M. R., \& Kelley, M. L. (2014). Predictors of cyberbullying perpetration among college students: An application of the Theory of Reasoned Action. Computers in Human Behavior, 36, 154-162. https://doi.org/10.1016/j.chb.2014.03.051

Domínguez-Hernández, F., Bonel, L., \& MartínezGonzález, A. (2018). A systematic literature review of factors that moderate bystanders' actions in cyberbullying. Cyberpsychology, 12(4
Special Issue). https://doi.org/10.5817/CP20184-1

Eloksari, E. (2020). Indonesian internet users hit 196 million, still concentrated in Java: APJII survey. The Jakarta Post.

Grunin, L., Yu, G., \& Cohen, S. S. (2020). The Relationship Between Youth Cyberbullying Behaviors and Their Perceptions of Parental Emotional Support. International Journal of Bullying Prevention. https://doi.org/10.1007/s42380-020-00080-5

Hellfeldt, K., López-Romero, L., \& Andershed, H. (2020). Cyberbullying and psychological wellbeing in young adolescence: the potential protective mediation effects of social support from family, friends, and teachers. International Journal of Environmental Research and Public Health, 17(1). https://doi.org/10.3390/ijerph17010045

Hemphill, S. A., \& Heerde, J. A. (2014). Adolescent predictors of young adult cyberbullying perpetration and victimization among australian youth. Journal of Adolescent Health, 55(4), 580587. https://doi.org/10.1016/j.jadohealth.2014.04.01 4

Langos, C. (2012). Cyberbullying: The challenge to define. Cyberpsychology, Behavior, and Social Networking, 15(6), 285-289. https://doi.org/10.1089/cyber.2011.0588

Li, Q. (2010). Cyberbullying in high schools: A study of students' behaviors and beliefs about this new phenomenon. Journal of Aggression, Maltreatment and Trauma, 19(4), 372-392. https://doi.org/10.1080/10926771003788979

López-Castro, L., \& Priegue, D. (2019). Influence of family variables on cyberbullying perpetration and victimization: A systematic literature review. Social Sciences, 8(3). https://doi.org/10.3390/socsci8030098

López-Meneses, E., Vázquez-Cano, E., GonzálezZamar, M. D., \& Abad-Segura, E. (2020). Socioeconomic effects in cyberbullying: Global research trends in the educational context. International Journal of Environmental Research and Public Health, 17(12), 1-31. https://doi.org/10.3390/ijerph17124369

Messias, E., Kindrick, K., \& Castro, J. (2014). School bullying, cyberbullying, or both: Correlates of teen suicidality in the 2011 CDC youth risk behavior survey. Comprehensive Psychiatry, 55(5), 10631068. https://doi.org/10.1016/j.comppsych.2014.02.0 05

Notar, C. E., Padgett, S., \& Roden, J. (2013). Cyberbullying : A Review of the Literature. Journal of Educational Research, 1(1), 1-9. https://doi.org/10.13189/ujer.2013.010101

Oliveira, F. R., de Menezes, T. A., Irffi, G., \& Oliveira, G. R. (2018). Bullying effect on student's performance. EconomiA, 19(1), 57-73. https://doi.org/10.1016/j.econ.2017.10.001 
Paisi-Lazarescu, M. (2014). Psychological Variables of Aggression at Teenagers. Procedia - Social and Behavioral Sciences, 127, 743-747. https://doi.org/10.1016/j.sbspro.2014.03.347

Palermiti, A. L., Servidio, R., Bartolo, M. G., \& Costabile, A. (2017). Cyberbullying and self-esteem: An Italian study. Computers in Human Behavior, 69, 136-141.

https://doi.org/10.1016/j.chb.2016.12.026

Ronis, S., \& Slaunwhite, A. (2019). Gender and Geographic Predictors of Cyberbullying Victimization, Perpetration, and Coping Modalities Among Youth. Canadian Journal of School Psychology, 34(1), 3-21. https://doi.org/10.1177/0829573517734029

Selkie, E. M., Fales, J. L., \& Moreno, M. A. (2016). Cyberbullying prevalence among US middle and high schoole-aged adolescents: A systematic review and quality assessment. Journal of Adolescent Health, 58(2), 125-133. https://doi.org/10.1016/j.jadohealth.2015.09.02 6

Sharma, D., Kishore, J., Sharma, N., \& Duggal, M. (2017). Aggression in schools: Cyberbullying and gender issues. Asian Journal of Psychiatry, 29, 142-145. https://doi.org/10.1016/j.ajp.2017.05.018

Shireen, F., Janapana, H., Rehmatullah, S., Temuri, H., \& Azim, F. (2014). Trauma experience of youngsters and Teens: A key issue in suicidal behavior among victims of bullying? Pakistan Journal of Medical Sciences, 30(1), 206-210. https://doi.org/10.12669/pjms.301.4072
Sindermann, C., Duke, É., \& Montag, C. (2020). Personality associations with Facebook use and tendencies towards Facebook Use Disorder. Addictive Behaviors Reports, 11(October 2019), 100264.

https://doi.org/10.1016/j.abrep.2020.100264

Sittichai, R., \& Smith, P. K. (2015). Bullying in SouthEast Asian Countries: A review. Aggression and Violent Behavior, 23, 22-35. https://doi.org/10.1016/j.avb.2015.06.002

Slaninova, G., Haviger, J., Novotna, L., Sochorova, P., \& Vackova, M. (2011). Relationship between cyberbullying and readiness for aggressive behavior in middle adolescence. Procedia - Social and Behavioral Sciences, 29, 567-573. https://doi.org/10.1016/j.sbspro.2011.11.277

Swearer, S. M., \& Hymel, S. (2015). Understanding the psychology of bullying: Moving toward a socialecological diathesis-stress model. American Psychologist, 70(4), 344-353. https://doi.org/10.1037/a0038929

Wade, A., \& Beran, T. (2011). Cyberbullying: The new Era of bullying. Canadian Journal of School Psychology, 26(1), 44-61. https://doi.org/10.1177/0829573510396318

Wiguna, T., Irawati Ismail, R., Sekartini, R., Setyawati Winarsih Rahardjo, N., Kaligis, F., Prabowo, A. L., \& Hendarmo, R. (2018). The gender discrepancy in high-risk behaviour outcomes in adolescents who have experienced cyberbullying in Indonesia. Asian Journal of Psychiatry, 37(July), 130-135. https://doi.org/10.1016/j.ajp.2018.08.021 